\title{
Antibacterial Potential of Zinc Oxide Nanoparticles Synthesized using Aloe vera (L.) Burm.f.: A Green Approach to Combat Drug Resistance
}

\author{
Chainika Khatana ${ }^{1}$, Ashwani Kumar ${ }^{2 *}$ (D) , Mashael W. Alruways ${ }^{3}$, \\ Nazam Khan ${ }^{3}$, Naveen Thakur ${ }^{4}$, Dinesh Kumar ${ }^{1}$ and Amita Kumari ${ }^{5}$ \\ ${ }^{1}$ Faculty of Applied Sciences and Biotechnology, Shoolini University, Solan - 173 212, Himachal Pradesh, India. \\ ${ }^{2}$ Patanjali Herbal Research Department, Patanjali Research Institute, Haridwar - 249 405, Uttarakhand, India. \\ ${ }^{3}$ Department of Clinical Laboratory Sciences, College of Applied Medical Sciences, Shaqra University, Shaqra, \\ Saudi Arabia. \\ ${ }^{4}$ Department of Physics, Career Point University, Hamirpur - 176 045, Himachal Pradesh, India. \\ ${ }^{5}$ School of Biological and Environmental Sciences, Shoolini University, Solan - 173 212, Himachal Pradesh, India.
}

\begin{abstract}
Microbial infections and antibiotic resistance are some of the prime factors that are ascribed to endanger human health. Several reports have highlighted that drug-resistant pathogens assist in the etiology of various chronic diseases and lead to fatality. The present study deciphered the role of zinc oxide nanoparticles (ZnO NPs) as therapeutics against selected bacterial strains. The plant-based technique was followed to synthesize ZnO NPs. The synthesis was confirmed with different techniques viz. X-ray diffraction, transmission electron microscope (interplanar spacing at $0.126 \mathrm{~nm}$ ), scanning electron microscope (flower-like structure), and Fourier transform infrared spectroscopy. The antibacterial analysis revealed that ZnO NPs inhibited the growth of all tested strains (Escherichia coli, Staphylococcus aureus, Salmonella typhi, Bacillus subtilis, and Klebsiella pneumoniae) to a greater extent (MIC ranged between $0.013 \pm 0.004-0.0625 \pm 0 \mathrm{mg} / \mathrm{mL}$ ) as compared with $\mathrm{ZnO}$ compound (Bulk material). In the present study, ZnO NPs were produced in a cost-effective and environmentally sustainable way using a green process and can be used as a remedy for drug-resistant pathogens.
\end{abstract}

Keywords: Aloe vera, Zinc oxide nanoparticles, Green synthesis, Characterization, Microbial pathogens

*Correspondence: ashu5157@gmail.com; +91 8894522997

(Received: June 13, 2021; accepted: September 03, 2021)

Citation: Khatana C, Kumar A, Alruways MW, et al. Antibacterial Potential of Zinc Oxide Nanoparticles Synthesized using Aloe vera (L.) Burm.f.: A Green Approach to Combat Drug Resistance. J Pure Appl Microbiol. 2021;15(4):1907-1914. doi: 10.22207/ JPAM.15.4.12

(C) The Author(s) 2021. Open Access. This article is distributed under the terms of the Creative Commons Attribution 4.0 International License which permits unrestricted use, sharing, distribution, and reproduction in any medium, provided you give appropriate credit to the original author(s) and the source, provide a link to the Creative Commons license, and indicate if changes were made. 


\section{INTRODUCTION}

Microbial diseases are one of the major causes of death worldwide. ${ }^{1,2}$ Scientists are working for the past many decades to develop antibiotics against different pathogenic bacterial strains. However, the misuse of such antibiotics is leading to antibiotic resistance that causes several fatalities every year. ${ }^{3,4}$ Bacterial strains like Staphylococcus aureus and Mycobacterium tuberculosis have already evaded every possible antibiotic in the clinician's armamentarium. Treating resistant microbes often requires more expensive or toxic drugs, resulting in further complications. ${ }^{5}$ Therefore, an innovative and novel approach is necessary to develop new antimicrobial drugs. ${ }^{6,7}$

Nanotechnology is one of the noble platforms for transforming basic compounds into nanoparticles (NPs) with enhanced properties. ${ }^{7-9}$ Nanomaterials are used in a wide range of medicinal and diagnostic applications. ${ }^{10}$ Several NPs have already been reported to be effective antimicrobials, including $\mathrm{ZnO}, \mathrm{MgO}, \mathrm{CuO}$, $\mathrm{Al}, \mathrm{TiO} 2, \mathrm{CdS}$, and $\mathrm{Au}^{11-18} \mathrm{NPs}$, in contrast to conventional medications, have a completely distinct mechanism for attacking microbes. ${ }^{19}$ The size and shape of the NPs are also important factors in their antibacterial action. ${ }^{20,21}$ As a result, the research focus is now shifting towards nanotechology to prevent microbial infections. Among various methods of synthesis of NPs, green synthesis, which encompasses synthesis using plants, bacteria, fungus, algae, actinomycetes, and other organisms, is environmentally friendly, cost-effective, biocompatible, and safe. ${ }^{22-25}$ Further, phyto-mediated synthesis is preferred to microbial synthesis, which requires time-consuming and costly downstream processing. ${ }^{26,27}$ The aim of this research is to synthesize zinc oxide nanoparticles (ZnO NPs) using Aloe vera leaf extract and investigate their antibacterial activity.

\section{MATERIALS AND METHODS Materials}

Aloe vera leaves were harvested in the local area of Solan, Himachal Pradesh, India, and washed with tween 20 followed with distilled water. Briefly, $100 \mathrm{~g}$ of the leaves (with gel) were chopped and dried at $40^{\circ} \mathrm{C}$ in an oven for $2 \mathrm{~h}$ followed by boiling in deionized water $(100 \mathrm{~mL})$. To remove particulate matter, the extract is subjected to filtration using Whatman paper and stored for 1-2 $\mathrm{h}$ at $4^{\circ} \mathrm{C}$.

Microbial strains viz. E. coli, Staphylococcus aureus, Salmonella typhi, Bacillus subtilis and Klebsiella pneumoniae were obtained from Post Graduate Institute of Medical Education and Research (PGIMER), Chandigarh, India.

\section{Green synthesis of ZnO NPs}

Briefly, $0.50 \mathrm{~g}$ zinc acetate was dissolved in $100 \mathrm{~mL}$ water and $8 \mathrm{~mL}$ freshly prepared Aloe vera leaves extract was added to the solution with constant stirring for $10 \mathrm{~min}$, and $\mathrm{pH}$ was adjusted to 12 with $\mathrm{NaOH}$. The resulting off-white color precipitates were thoroughly washed with water, filtered, and dried in a $60^{\circ} \mathrm{C}$ oven. The obtained product was grounded into refined grains in a mortar and stored for further use and labeled as ZnO NPs.

\section{Characterization of ZnO NPs}

Scanning electron microscopy (SEM), and transmission electron microscopy (TEM) were used to investigate the morphological characteristics of ZnO NPs. ${ }^{28,29}$

The FEl Nova Nano SEM 450 at $1 \mathrm{kV}$ was used to generate SEM micrographs, and TEM images were taken using FP/5022-Tecnai G220STWIN (USA) at 200 kV. Agilent Cary-630 FTIR was also used to analyze the characteristic functional groups between 4000 to $400 \mathrm{~cm}^{-1}$ spectrum range. The crystal structure of fabricated $\mathrm{ZnO}$ was determined by X-ray diffraction (XRD, PANalytical's $X$ 'Pert Pro), the pattern was obtained with CuK $\alpha 1$ radiation $(45 \mathrm{kV} / 100 \mathrm{~mA})$, scanning was done at a rate of $2^{\circ} / \mathrm{min}$ in the diffraction angles $(2 \theta)$, which ranged from 20 to $70^{\circ}$.

\section{Antibacterial activity of ZnO NPs}

A modified disc diffusion method was performed to investigate the antibacterial potential of the $\mathrm{ZnO}$ compound and $\mathrm{ZnO} \mathrm{NPs}^{30}$ The NPs were suspended in methanol to make a stock solution with a concentration of $10 \mathrm{mg} /$ $\mathrm{mL}$. The resulting solution was then sonicated (15 $\mathrm{min}$ ) before antibacterial evaluation. On the other hand, isolated colonies (4-5) were transferred into a test tube containing nutrient broth medium ( 5 $\mathrm{mL}$ ), followed by 24 hours incubation at $37^{\circ} \mathrm{C} .0 .5$ McFarland standard $\left(1-2 \times 10^{8} \mathrm{CFU} / \mathrm{mL}\right)$ was used to compare the turbidity of inoculums. 


\section{Disc diffusion assay}

Briefly, $100 \mu \mathrm{l}$ inoculums (107-10 CFU/ $\mathrm{mL}$ ) were uniformly spreaded on Mueller Hinton agar (MHA) plates. The discs (6 mm, Whatman filter paper no. 1) were prepared by adding $30 \mu \mathrm{L}$ of different concentration of NPs. After that, discs with varying concentrations $(2,4,6 \mathrm{mg} / \mathrm{mL})$ of $\mathrm{ZnO}$ compound and $\mathrm{ZnO}$ NPs were placed on these MHA plates. Tetracycline was used as a standard drug $(30 \mu \mathrm{g} / \mathrm{mL})$, while methanol was employed as a negative control. Further, the MHA plates were kept at $37^{\circ} \mathrm{C}$ and inhibition zone diameter $(\mathrm{mm})$ was measured after 24 hours.

Determination of minimum inhibitory concentration (MIC) of ZnO NPs

The MIC was determined using the CLSI M7-A7 broth microdilution method. ${ }^{31}$ For this, a double-strength Mueller-Hinton broth (MHB), NPs solution ( $2 \mathrm{X}$ ) were prepared, followed by its serial dilutions in the range $2-0.0 .0039 \mathrm{mg} / \mathrm{mL}$ in a 96 well microtitre plate. Double strength MHB $(100 \mu l)$ containing varied NPs concentrations was
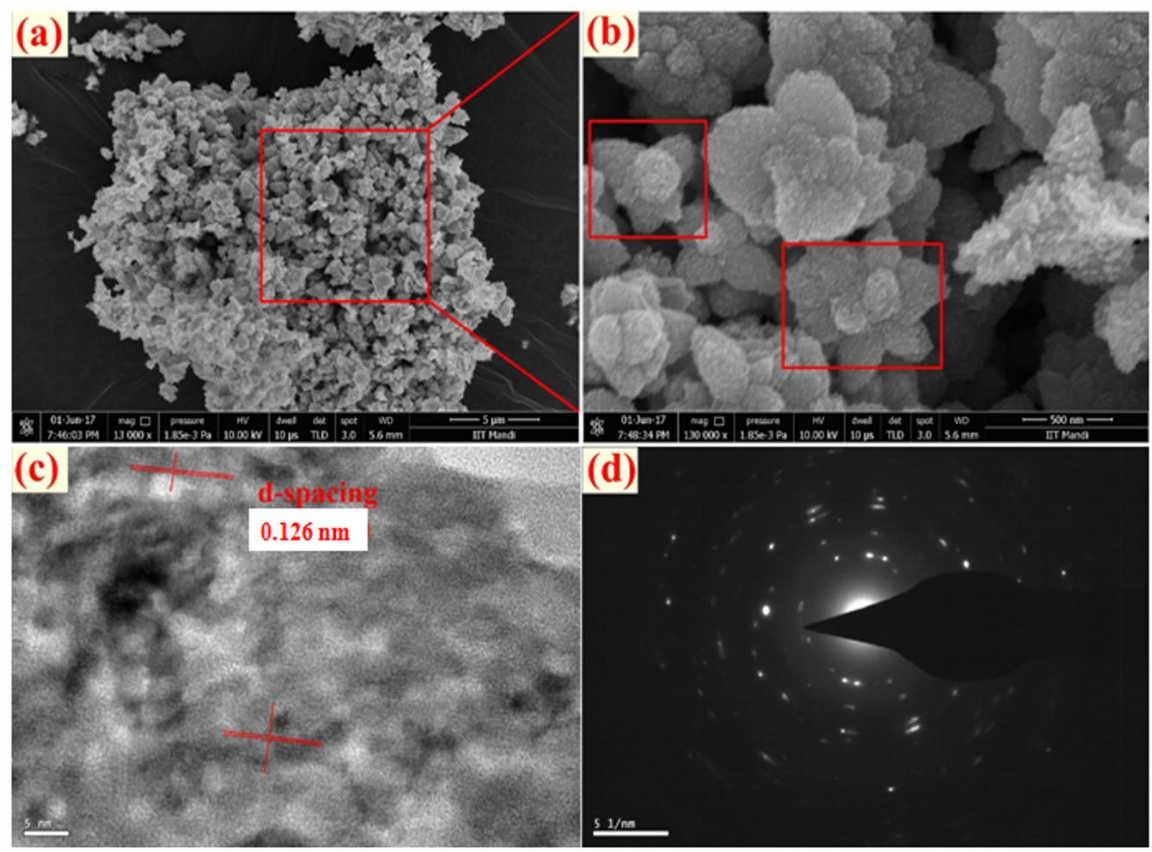

Fig. 1. Morphological assessment of ZnO NPs (a, b) SEM images, (c) TEM image and (d) SAED pattern.

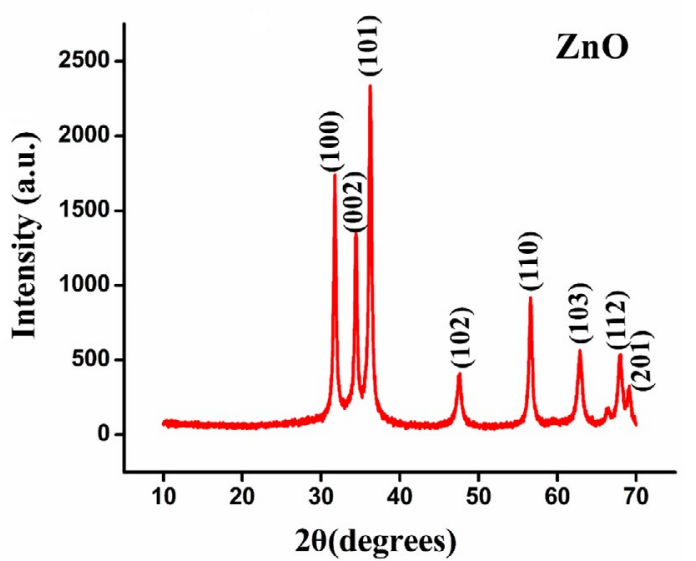

Fig. 2. ZnO nanoparticles' X-ray diffraction spectrum. mixed with bacterial inoculum $(10 \mu \mathrm{L})$ containing $1-2 \times 10^{8} \mathrm{CFU} / \mathrm{mL}$. On the other hand, the $10^{\text {th }}$ well (broth + inoculums) was used as a control. In addition, the $11^{\text {th }}$ well was utilized as positive control (antibiotics + inoculums) and the $12^{\text {th }}$ well as negative control (methanol + inoculums). After this, the microtitre plate was kept at $37^{\circ} \mathrm{C}$, for 24 hours. The lowest visual growth inhibitory concentration was considered MIC.

Determination of minimum bactericidal concentration (MBC) of ZnO NPs

MBC was determined by spreading suspensions $(10 \mu \mathrm{l})$ from microtiter plate wells over a nutrient agar plate and incubating at 
$37^{\circ} \mathrm{C}$ for $24 \mathrm{~h}$. Agar plates with no colonies were considered as MBC.

\section{Statistical analysis}

GraphPad Prism 5.0 was used to examine the results obtained (where applicable) using average, analysis of variance, and standard deviation. A p value $<0.05$ was considered to be statistically significant.

\section{RESULTS AND DISCUSSION \\ Morphology and phase structure composition of ZnO NPs}

The SEM images of $\mathrm{ZnO}$ revealed uniform distribution of flower-like morphology (Fig. 1a and 1b), which could be correlated with the previously reported literature. ${ }^{32}$ From TEM images, surface morphology and size were estimated (Fig. 1c), and showed interplanar spacing at $0.126 \mathrm{~nm}$, which were well distributed, and corresponded to standard reported values. ${ }^{33}$ The SAED image (Fig. 1d) revealed small bright spots representing the poly-nano crystalline nature of the ZnO NPs. Similar findings were observed by Cao et al. ${ }^{34}$

To decipher the crystal structure, XRD patterns were analyzed and are presented in Fig. 2. The patterns of $\mathrm{ZnO}$ NPs which are positioned at $2 \theta$ values of $31.5,34.2,36.1,47.4,56.5,62.8,68.8$, and $69.0^{\circ}$ can be attributed to $100,002,101,102$,

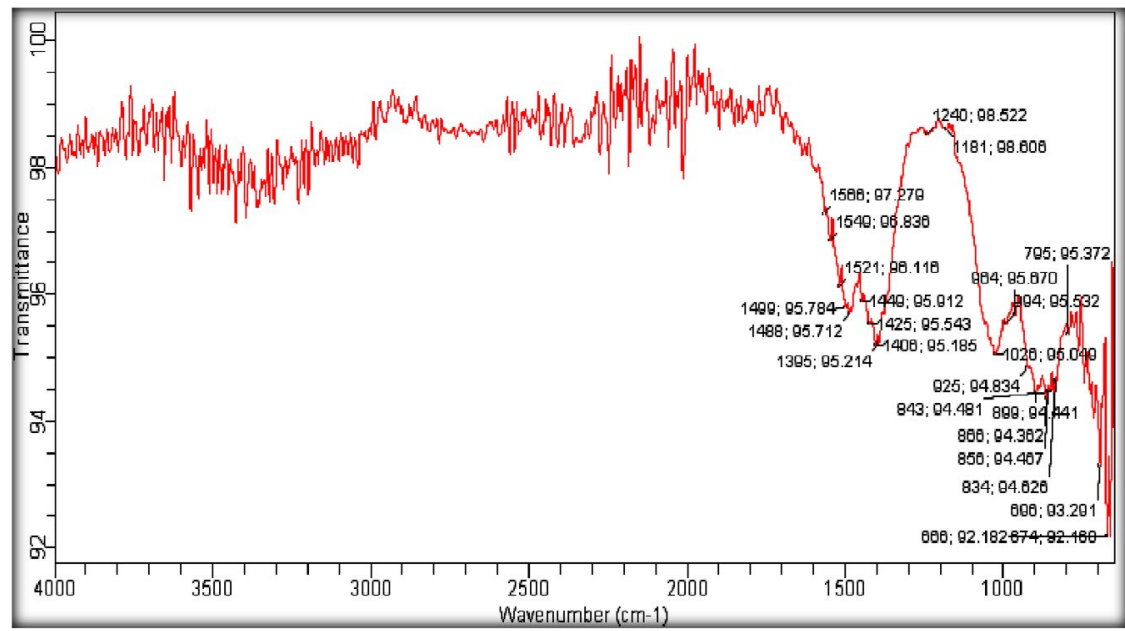

Fig. 3. FTIR spectrum of ZnO NPs.

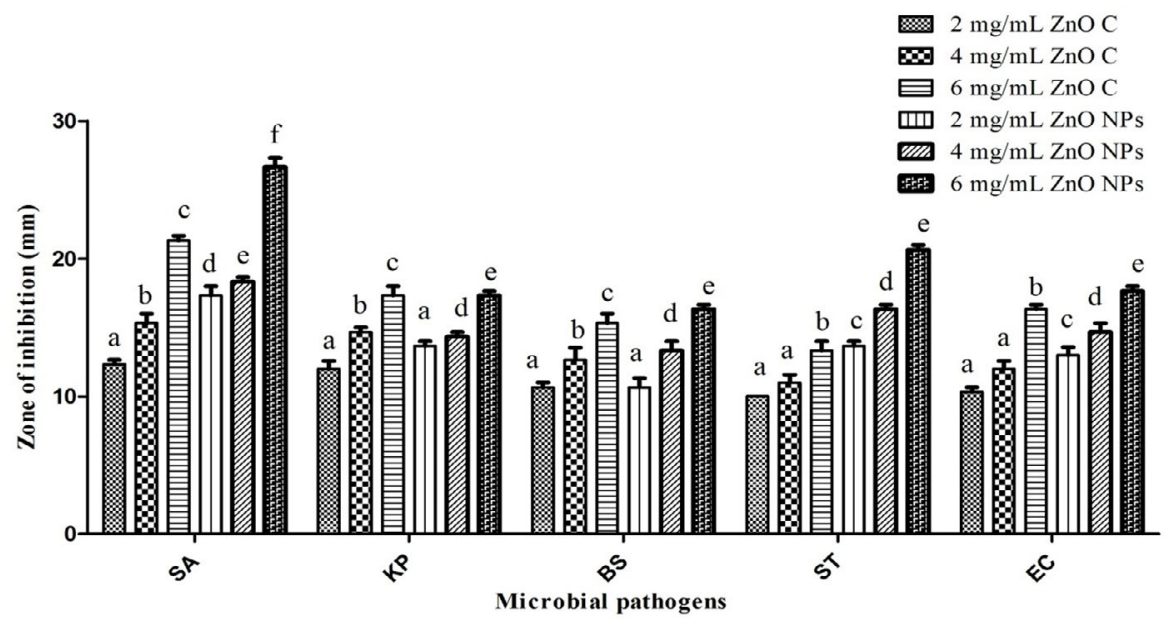

Fig. 4. Inhibition zone diameter of $\mathrm{ZnO}$ Compound $(\mathrm{ZnO} \mathrm{C})$ and $\mathrm{ZnO} N \mathrm{Ns}$ at varying concentrations against bacterial pathogens. Different letters were used when mean values were statistically significant $(p<0.05)$. SA-Staphylococcus aureus; KP- Klebsiella pneumoniae; BS- Bacillus subtilis; EC- Escherichia coli; ST- Salmonella typhi. 
110, 103, 112 and 201 planes of ZnO NPs. Similar results have been reported earlier for $\mathrm{ZnO} N \mathrm{NP}$ by Parthasarathy et al. ${ }^{35}$ and Alamdari et al. ${ }^{36}$ The peaks corresponded to the standard card's values (JCPDS 36-1451). ${ }^{37}$ Moreover, using the Scherrer equation, the crystalline size of synthesized NPs on average was $15.6 \mathrm{~nm}(D=K \lambda / \beta \cos \theta)$. Constant $K$ was adjusted to be 0.89 , diffracting angle is $\theta$, the wavelength $(\lambda)$ (CuK $\alpha=0.15406 \mathrm{~nm})$, and $\beta$ is the line width at half maximum height of the peak.
FTIR spectra shown in Fig. 3 show plenteous structural information of prepared NPs. The $\mathrm{ZnO}$ stretching modes could be associated with the absorption peak in the $600-700 \mathrm{~cm}^{-1}$ range. Absorption peak between $1100-1600 \mathrm{~cm}^{-1}$ corresponds to the $\mathrm{OH}, \mathrm{C}-\mathrm{OH}$ bending, and $\mathrm{C}-\mathrm{OH}$ out of plane bending. Further, $\mathrm{O}-\mathrm{H}$ stretching modes and $\mathrm{C}-\mathrm{H}$ stretching modes overlap in $2000-3700 \mathrm{~cm}^{-1}$ region. The adsorption band at $1181.98 \mathrm{~cm}^{-1}$ denotes the $\mathrm{C}=\mathrm{O}$ vibrations of

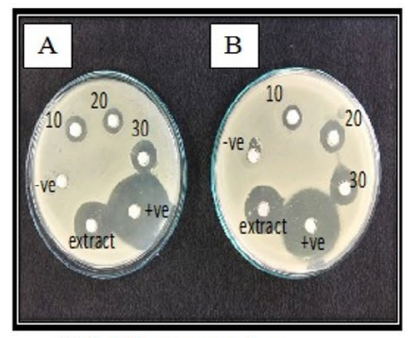

Klebsiella pneumoniae

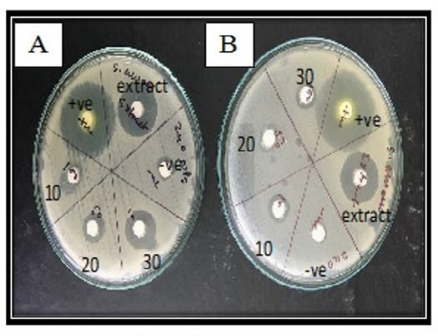

Staphylococcus aureus

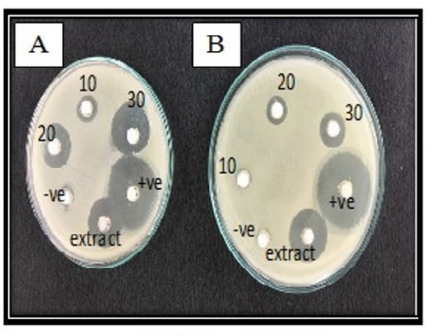

Salmonella typhi

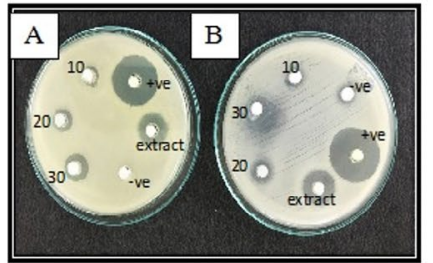

Bacillus subtilis

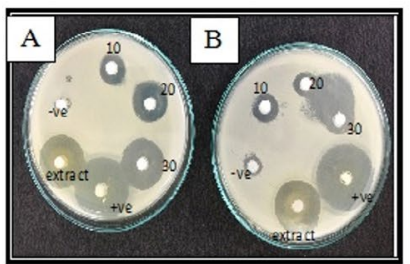

Escherichia coli

Fig. 5. Antibacterial potential of $\mathrm{ZnO} N P s(A)$ and $\mathrm{ZnO}$ compound $(\mathrm{B})$ at varying concentrations $(10,20$ and $30=2$, 4 and $6 \mathrm{mg} / \mathrm{mL}$ ); Negative control- Methanol; Positive control- Tetracycline.

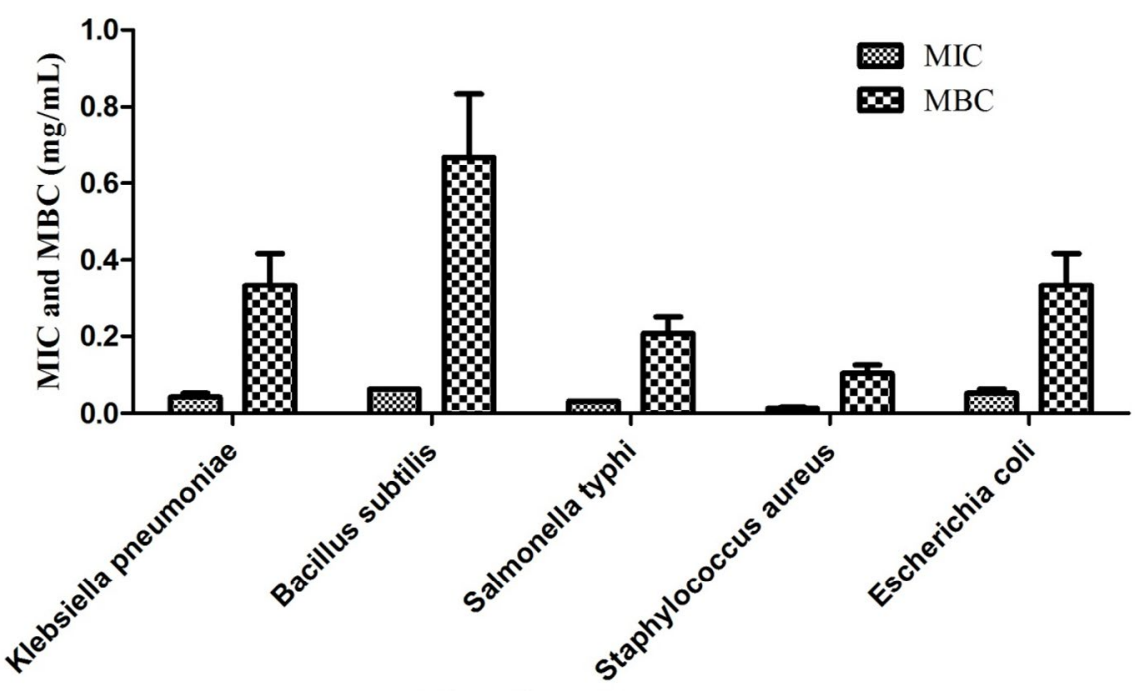

Microbial pathogens

Fig. 6. ZnO nanoparticles' MIC and MBC values against microbial pathogens 
carboxylic acids, alcohols. Similar observations have been reported by Sangeetha et al. ${ }^{38}$ There was a strong absorption at $528 \mathrm{~cm}^{-1}$, and there were peaks at 3451,1552, 2170, and $1399 \mathrm{~cm}^{-1}$, which corresponds to the $-\mathrm{OH}, \mathrm{N}-\mathrm{H}, \mathrm{C}=\mathrm{C}$, and $\mathrm{C}-\mathrm{H}$ bond stretching, respectively.

\section{Antibacterial activity of ZnO NPs}

In antibacterial activity study, the effect of $\mathrm{ZnO}$ NPs is more pronounced as compared with $\mathrm{ZnO}$ compound $(2-6 \mathrm{mg} / \mathrm{mL})$. Both tested samples exhibited broad-spectrum antibacterial effect towards all selected bacterial strains and the inhibition zone diameter ranged between $10 \pm 0$ to $28 \pm 1.7 \mathrm{~mm}$. The highest inhibition zone diameter i.e. $28 \pm 1.7 \mathrm{~mm}$ was reported against $S$. aureus with ZnO NPs at $6 \mathrm{mg} / \mathrm{mL}$, while the lowest $(10 \pm 0)$ was observed against Salmonella typhi at $2 \mathrm{mg} /$ $\mathrm{mL}$ of $\mathrm{ZnO}$ compound (Fig. 4 and 5). On the other hand, standard tetracycline showed inhibition zone diameter ranged between $25 \pm 1$ to $34 \pm 0.52$ against all tested microbes, while negative control methanol did not show any activity. Dobrucka and Długaszewska also reported the positive antibacterial effect of green synthesized $\mathrm{ZnO}$ NPs against $S$. aureus, E. coli, and Pseudomonas aeruginosa and showed the highest inhibition zone of $31 \mathrm{~mm}$ against $S$. aureus. ${ }^{39}$

The MIC as well as MBC values correlate well with the disc diffusion assay. The highest MIC $(0.0625 \pm 0 \mathrm{mg} / \mathrm{mL})$ and MBC $(1 \pm 0.29 \mathrm{mg} /$ $\mathrm{mL}$ ) were observed against Bacillus subtilis. On the other hand, the lowest MIC $(0.013 \pm 0.01$ $\mathrm{mg} / \mathrm{mL})$ and $M B C(0.10 \pm 0.04 \mathrm{mg} / \mathrm{mL})$ were observed against Staphylococcus aureus (Fig. 6). Thakur et al. reported similar activity with green synthesized titanium dioxide NPs. ${ }^{18}$ Subsequently, only E. coli and Aspergillus niger were found to be susceptible to $\mathrm{ZnO}$ NPs made using Aloe vera extract. ${ }^{40}$ Similarly, $\mathrm{ZnO}$ synthesized using Aloe vera exhibited activity against E. coli. ${ }^{33}$

Several mechanisms have been suggested to explain the antibacterial behavior of NPs, such as the deactivation of cellular enzymes, and DNA via coordination with the donor groups of electrons; and the creation of pits in bacterial cell walls, resulting in increased permeability and, in the end, cell death. Interestingly, hydrogen peroxide development from the $\mathrm{ZnO}$ surface is considered to be an effective means of inhibiting bacterial growth. ${ }^{41}$ On the other hand, one of the plausible reasons for $\mathrm{ZnO}$ antibacterial activity is the production of $\mathrm{Zn}^{2+}$ ions, which can disrupt the cell membrane and interfere with cellular content. $^{42}$

\section{CONCLUSION}

In conclusion, Aloe vera leaves extract mediated synthesis of ZnO NPs is achieved, and this green synthesis is attributed to L-ascorbic acid and bioactive components present in the leaves of Aloe vera. The green approach used for synthesis is environment-friendly. Both $\mathrm{ZnO}$ compound and ZnO NPs successfully inhibited the growth of all tested bacterial pathogens including Grampositive as well as negative cultures. However, the potential of ZnO NPs is found higher as compared with its compound. It was concluded that $\mathrm{ZnO}$ NPs could be used as drug-developing candidates after follow-up studies. Further studies are being carried out to assess the impact of various storage conditions on the stability of ZnO NPs.

\section{ACKNOWLEDGMENTS}

The authors are grateful to the Indian Institute of Technology, Mandi, India, for providing the necessary facilities for the characterization work.

\section{CONFLICT OF INTEREST}

The authors declare that there is no conflict of interest.

\section{AUTHORS' CONTRIBUTION}

All authors listed have made a substantial, direct and intellectual contribution to the work, and approved it for publication.

\section{FUNDING}

None.

\section{DATA AVAILABILITY}

All datasets generated or analyzed during this study are included in the manuscript.

\section{ETHICS STATEMENT}

Not applicable.

\section{REFERENCES}

1. Lozano R, Naghavi M, Foreman K, et al. Global and regional mortality from 235 causes of death for 20 
age groups in 1990 and 2010: A systematic analysis for the global burden of disease study. Lancet. 2012;380(9859):2095-2128. doi: 10.1016/S01406736(12)61728-0

2. Salomon JA, Wang $\mathrm{H}$, Freeman $\mathrm{MK}$, et al. Healthy life expectancy for 187 countries, 1990-2010: A systematic analysis for the global burden disease study 2010. Lancet. 2012;380(9859):2144-2162. doi: 10.1016/ S0140-6736(12)61690-0

3. Ventola CL. The antibiotic resistance crisis: part 1: causes and threats. Pharm Ther. 2015;40:277-283.

4. Balkrishna A, Rohela, A, Kumar A, et al. Mechanistic insight into antimicrobial and antioxidant potential of Jasminum species: A herbal approach for disease management. Plants. 2021;10(6):1089. doi: 10.3390/ plants10061089

5. Webb G. Learning through teaching: a microbiology service-learning experience. J Microbiol Biol Educ. 2016;17(1):86-89. doi: 10.1128/jmbe.v17i1.997

6. Melaiye A, Youngs WJ. Silver and its application as an antimicrobial agent. Expert Opin Ther Pat. 2005;15(2):125-130. doi: 10.1517/13543776.15.2.125

7. Marcato PD, Duran N. New aspects of nanopharmaceutical delivery systems. J Nanosci Nanotechnol. 2008;8(5):2216-2229. doi: 10.1166/ jnn.2008.274

8. Duran N, Marcato PD, Alves OL, De Souza GI, Esposito E. Mechanistic aspects of biosynthesis of silver nanoparticles by several Fusarium oxysporum strains. J Nanobiotechnol. 2005;3:8. doi: 10.1186/1477-31553-8

9. Singh $P$, Shandilya $P$, Raizada $P$, Sudhaik A, RahmaniSani A, Hosseini-Bandegharaei A. Review on various strategies for enhancing photocatalytic activity of graphene based nanocomposites for water purification. Arab J Chem. 2020;13(1):3498-3520. doi: 10.1016/j.arabjc.2018.12.001

10. Tartaj P, Morales MP, Gonzalez-Carreno T, VeintemillasVerdaguer S, Serna CJ. Advances in magnetic nanoparticles for biotechnology applications. Journal of Magnetism and Magnetic Materials. 2005;290291(Part 1):28-34. doi: 10.1016/j.jmmm.2004.11.155

11. Morones JR, Elechiguerra JL, Camacho A, Holt K, Kouri JB, Ramirez JT, Yacaman MJ. The bactericidal effect of silver nanoparticles. Nanotechnology. 2005;16(10):2346-2353. doi: 10.1088/09574484/16/10/059

12. Shankar SS, Rai A, Ahmad A, Sastry M. Rapid synthesis of $\mathrm{Au}, \mathrm{Ag}$, and bimetallic Au core-Ag shell nanoparticles using Neem (Azadirachta indica) leaf broth. J Colloid Interface Sci. 2004;275(2):496-502. doi: 10.1016/j. jcis.2004.03.003

13. Kumar A, Singh S, Kumar D. Evaluation of antimicrobial potential of cadmium sulphide nanoparticles against bacterial pathogens. Int J Pharm Sci Res. 2014;24:202207.

14. Parthasarathy G, Saroja M, Venkatachalam M, Shankar S, Evanjelene VK. Green synthesis of zinc oxide nanoparticles-review paper. World J Pharm Pharm Sci. 2016;5:922-931.

15. Shanmugapriya J, Monisha P, Nandhini A, Praveena K. Synthesis of zinc oxide nanoparticles from Aloe barbadensis for medical application. Int J Adv Res Technol. 2019;7:1-10.

16. Jayappa MD, Ramaiah CK, Kumar MAP, et al. Green synthesis of zinc oxide nanoparticles from the leaf, stem and in vitro grown callus of Mussaenda frondosa L.: characterization and their applications. Appl Nanosci. 2020;10:3057-3074. doi: 10.1007/s13204020-01382-2

17. Thakur N, Anu, Kumar K. Effect of (Ag, Co) Co-doping on the structural and antibacterial efficiency of $\mathrm{CuO}$ nanoparticles: A rapid microwave assisted method. $J$ Environ Chem Eng. 2020;8(4):104011. doi: 10.1016/j. jece.2020.104011

18. Thakur BK, Kumar A, Kumar D. Green synthesis of titanium dioxide nanoparticles using Azadirachta indica leaf extract and evaluation of their antibacterial activity. S Afr J Bot. 2019;124:223-227. doi: 10.1016/j. sajb.2019.05.024

19. Pal M, Garcia Serrano J, Santiago P, Pal U. Sizecontrolled synthesis of spherical TiO2 nanoparticles: morphology, crystallization, and phase transition. J Phys Chem C. 2007;111(1):96-102. doi: 10.1021/ jp0618173

20. Elechiguerra JL, Burt JL, Morones JR, et al. Interaction of silver nanoparticles with HIV-1. J Nanobiotechnol. 2005;3:6. doi: 10.1186/1477-3155-3-6

21. Gurunathan S, Han JW, Kwon DN, Kim JH. Enhanced antibacterial and anti-biofilm activities of silver nanoparticles against Gram-negative and Grampositive bacteria. Nanoscale Res Lett. 2014;9(1):1-17. doi: 10.1186/1556-276x-9-373

22. Mclnnes C. Virtual screening strategies in drug discovery. Curr Opin Chem Biol. 2007;11(5):494-502. doi: 10.1016/j.cbpa.2007.08.033

23. Galkina KV, Besedina EG, Zinovkin RA, Severin FF, Knorre DA. Penetrating cations induce pleiotropic drug resistance in yeast. Sci Rep. 2018;8:8131. doi: 10.1038/ s41598-018-26435-z

24. Kavitha KS, Baker S, Rakshith D, et al. Plants as green source towards synthesis of nanoparticles. Int Res J Biol Sci. 2013;2:66-76.

25. Zahir AA, Chauhan IS, Bagavan A, et al. Synthesis of nanoparticles using Euphorbia prostrata extract reveals a shift from apoptosis to G0/G1 arrest in Leishmania donovani. J Nanomed Nanotechnol. 2014;5:1-12.

26. Narayanan KB, Sakthivel N. Green synthesis of biogenic metal nanoparticles by terrestrial and aquatic phototrophic and heterotrophic eukaryotes and biocompatible agents. Adv Colloid Interface Sci. 2011;169(2):59-79. doi: 10.1016/j.cis.2011.08.004

27. Bhardwaj K, Dhanjal DS, Sharma A, et al. Coniferderived metallic nanoparticles: Green synthesis and biological applications. Int J Mol Sci. 2020;21(9088):122. doi: $10.3390 /$ ijms 21239028

28. Ahmed B, Solanki B, Zaidi A, Khan MS, Musarrat J. Bacterial toxicity of biomimetic green zinc oxide nanoantibiotic: insights into ZnONP uptake and nanocolloid-bacteria interface. Toxicol Res. 2019;8:246261. doi: 10.1039/C8TX00267C

29. Ahmed B, Ameen F, Rizvi A, et al. Destruction of cell topography, morphology, membrane, inhibition 
of respiration, biofilm formation, and bioactive molecule production by nanoparticles of $\mathrm{Ag}, \mathrm{ZnO}$, $\mathrm{CuO}, \mathrm{TiO}_{2}$, and $\mathrm{Al}_{2} \mathrm{O}_{3}$ toward beneficial soil bacteria. ACS Omega. 2020;5(14):7861-7876. doi: 10.1021/ acsomega.9b04084

30. Bauer AW, Kirby WMM, Sherris JC, Turck M. Antibiotic susceptibility testing by a standardized single disc method. Am J Clin Pathol. 1966;45:493-496. doi: 10.1093/ajcp/45.4_ts.493

31. Chemical Laboratory Standards Institute. Methods for dilution antimicrobial susceptibility tests for Bacteria that grow aerobically; Approved Standard, Seventh ed., CLSI Document M7- A7, Wayne, Pennsylvania, USA. 2006.

32. Qiu J, Weng B, Zhao L, et al. Synthesis and characterization of flower-like bundles of $\mathrm{ZnO}$ nanosheets by a surfactant-free hydrothermal process. J Nanomater. 2014;2014:281461. doi: 10.1155/2014/281461

33. Rasli NI, Basri $\mathrm{H}$, Harun Z. Zinc oxide from Aloe vera extract: two-level factorial screening of biosynthesis parameters. Heliyon. 2020;6(1):e03156. doi: 10.1016/j. heliyon.2020.e03156

34. Cao D, Gong S, Shu X, Zhu D, Liang S. Preparation of ZnO nanoparticles with high dispersibility based on oriented attachment (OA) process. Nanoscale Res Lett. 2019;14(1):210. doi: 10.1186/s11671-019-3038-3

35. Parthasarathy G, Saroja M, Venkatachalam M, Evanjelene VK. Biological synthesis of zinc oxide nanoparticles from leaf extract of Curcuma neilgherrensis Wight. Int J Mat Sci. 2017;12(1):73-86.
36. Alamdari S, Ghamsari MS, Lee C, et al. Preparation and characterization of zinc oxide nanoparticles using leaf extract of Sambucus ebulus. Appl Sci. 2020;10(10):3620. doi: 10.3390/app10103620

37. Khan MF, Ansari AH, Hameedullah M, et al. Sol-gel synthesis of thorn-like $\mathrm{ZnO}$ nanoparticles endorsing mechanical stirring effect and their antimicrobial activities: Potential role as nano-antibiotics. Sci Rep. 2016;6:27689. doi: 10.1038/srep27689

38. Sangeetha G, Rajeshwari S, Venckatesh R. Green synthesis of zinc oxide nanoparticles by Aloe barbadensis miller leaf extract: Structure and optical properties. Mater Res Bull. 2011;46(12):2560-2566. doi: 10.1016/j.materresbull.2011.07.046

39. Dobrucka R, Dlugaszewska J. Biosynthesis and antibacterial activity of $\mathrm{ZnO}$ nanoparticles using Trifolium pratense flower extract. Saudi J Biol Sci. 2016;23(4):517-523. doi: 10.1016/j.sjbs.2015.05.016

40. Chaudhary A, Kumar N, Kumar R, Salar RK. Antimicrobial activity of zinc oxide nanoparticles synthesized from Aloe vera peel extract. SN Appl. Sci. 2019;1:136. doi: 10.1007/s42452-018-0144-2

41. Yamamoto 0 . Influence of particle size on the antibacterial activity of zinc oxide. Int J Inorg Mater. 2001;3(7):643-646. doi: 10.1016/S14666049(01)00197-0

42. Brayner R, Ferrari-lliou FN, Brivois S, Djediat MF, Benedetti, Fievet F. Toxicological impact studies based on Escherichia coli bacteria in ultrafine ZnO nanoparticles colloidal medium. Nano Lett. 2006;6(4):866-870. doi: 10.1021/nl052326h 